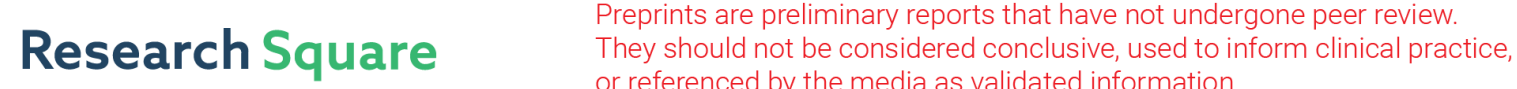 or referenced by the media as validated information. \\ Green Building Performance Assessment in China Using a Cloud Model
}

\section{Xiao-Juan Li}

Fujian Agriculture and Forestry University

Chen Wang ( $\nabla$ derekisleon@gmail.com )

Huaqiao University https://orcid.org/0000-0001-7892-3575

\section{Shilpi Bora}

Huaqiao University

\section{Bimenyimana Samuel}

Huaqiao University

\section{Original article}

Keywords: green building, cloud model, uncertainty, performance assessment

Posted Date: October 6th, 2020

DOI: https://doi.org/10.21203/rs.3.rs-81355/v1

License: @ (i) This work is licensed under a Creative Commons Attribution 4.0 International License. Read Full License 


\title{
Green Building Performance Assessment in China Using a Cloud Model
}

\author{
Xiao-Juan $\mathrm{Li}^{1}$, Chen $\mathrm{Wang}^{2}$, Shilpi Bora ${ }^{3}$, Bimenyimana Samuel ${ }^{4}$ \\ 1, Associate Professor, College of Transportation and Civil Engineering, Fujian agriculture and forestry university, Fuzhou, Fujian \\ Province, 350108, P.R. China. Email: xiaojuanli@fafu.edu.cn \\ 2, Distinguished Professor, Director of Intelligence and Automation in Construction Fujian Province Higher-educational Engineering \\ Research Centre, College of Civil Engineering, Huaqiao University, 361021, Xiamen, China. Email: wch@ @qu.edu.cn \\ 3, Post-Doctoral Research Fellow, Intelligence and Automation in Construction Fujian Province Higher-educational Engineering \\ Research Centre, College of Civil Engineering, Huaqiao University, 361021, Xiamen, China. Email: shilpi.ergonomics@ gmail.com \\ 4, Post-Doctoral Research Fellow, Intelligence and Automation in Construction Fujian Province Higher-educational Engineering \\ Research Centre, College of Civil Engineering, Huaqiao University, 361021, Xiamen, China. Email: sagepelican@ yahoo.fr \\ Corresponding Author: Distinguished Professor Dr. Chen Wang \\ Corresponding Email: derekisleon@gmail.com, wch@hqu.edu.cn
}

\begin{abstract}
Background. The recent pursuit of energy conservation, emission reduction, and sustainable development are the demanding aspect in green building construction. Green building concept becomes important in the current building life cycle to mitigate environmental issues. In this way, a strategy for surveying the performance of a green structure is attractive. Consequently, this investigation intends to build up a methodical methodology for distinguishing the elements that decide the effective development and activity of a green structure and makes a technique for assessing green building execution.
\end{abstract}

Methods. To accomplish these objectives, a comprehensive literature review was first conducted, followed by determining the performance of a green building to create a qualitative fuzzy set of performance metrics. A cloud model was used to analyze the factor hierarchy using weighted entropy to quantify the performance of a green building. Ultimately, an inside and out contextual analysis was led to check the exact discoveries.

Results. A green building performance index that was created based on expert evaluations and weighted the indexes subjectively and objectively. Likewise, a standard cloud yardstick was also created in the comprehensive cloud. The sustainability of the building was qualified and assessed by comparing cloud images with the standard cloud. It has been analyzed that, the execution measurements and persuasive components make appraisal models for a green building. This investigation can help the development business to distinguish and manage issues that emerge in building green buildings. The coherent framework that the researchers have developed for assessing green buildings provides a solid foundation for further research into sustainability and green building operation. The result indicates that the industry acquires benefit by suggesting effective measures that can be implemented in all stages of green building construction.

Conclusion. The analysis results demonstrated that this investigation builds up a novel exhibition appraisal of a green building which makes a target establishment for assessing building execution. Additionally, the findings are helpful for industry specialists to improve green building construction. Besides, the outcomes give significant data to governments and other invested individuals to create target models for green building development programs.

Keywords: green building; cloud model; uncertainty; performance assessment.

\subsection{Introduction}

The global construction industry is the greatest industrial energy consumed and the greatest polluter of the natural environment. Raw materials consumed annually by the construction industry account for about $44 \%$ of global raw material use [1]. The consumption of this huge quantity of natural resources degrades natural environmental degradation [2]. At the time of $2018,70 \%$ of the world's energy is devoured by developed countries, which represent just $22 \%$ of the total populace. In Canada, the United Kingdom, and the United States, buildings are responsible for 30-50\% of the country's energy needs $[1,3]$, and construction produces $25-48 \%$ of carbon dioxide emissions. 
50 The interest for energy utilized in building development and use in developing nations; carbon outflows and the 51 utilization of power are expanding quickly [4]. For instance, the development represents 33\% of India's energy consumption, which is developing by $8 \%$ consistently [5]. Chaturvedi et al. [6] anticipated that energy consumption in India's construction sector would expanding over $500 \%$ by 2100 without explicit industry approaches to limit the utilization of building energy. The development business should move toward green and sustainable development to reduce the adverse impact of buildings on the environment [7]. Green buildings are buildings that augment the utilization of assets and space, decrease ecological contamination, and live in harmony with nature [8]. Green structure idea is the idea with benevolent condition structures that obliged the interests of ecological, social, and financial joining parts of structures as indicated by guidelines that it has been resolved from the structure life cycle plan. Some proponents of green building concepts walk with the owner's needs of the building, rating tools and knowledge, government aid, and government regulations. A worthwhile green building assessment tool should enable us to assess the lifetime sustainability of a green building during the planning, construction, operation, and destruction of the building. It will indicate if best practices, which reduce the adverse impacts of construction on the natural environment, were included in the building life cycle.

\subsection{Latest Developments on Green Building Performance Assessment}

66

With the introduction of green building, the first green building performance assessment method to have been developed was the Building Research Establishment Environmental Assessment Method (BREEAM) created by building research institutions in 1990. It contains several specific evaluation systems, each of which was intended for a particular kind of building, consequently, BREEAM applies to structures. It likewise contains conventions for explicit nations, such as the Netherlands, Norway, Sweden, and Spain. Different nations have created frameworks to assess the impacts of green buildings on the natural environment, such as the Green Building Tool (GB Tool) in 1996, the Leadership in Energy and Environmental Design Scheme (LEED) in 1998, and the Comprehensive Assessment System for Building Environmental Efficiency (CASBEE) in 2001.

GB Tool, developed by the International Framework Committee for Green Building Challenge, is utilized in 25 countries. The tool evaluates project location, project planning and development, environmental load, energy and resource consumption, indoor environmental quality, function, long-term performance, and social and economic aspects of a green building. LEED is an agreement based building rating framework for a new advertisement, institutional, and skyscraper private buildings, and significant redesign anticipates for existing buildings. It was developed by the U.S. Green Building Council. Green Globe is a green building evaluation tool adopted by the Building Owners and Managers Association (BOMA) in Canada to evaluate the environmental performance and interior design of new and existing buildings. This evaluation tool is crucial to Canada's national environmental planning [4, 8, 9]. China, following different nations, has presented development philosophies and far-reaching green building appraisal norms to oversee the improvement of green buildings in China as in Table 1. Widespread green building construction transforms the construction industry economics and technology. Cultural change is required to normalize the concept of sustainable development. There has been minimal green building construction in China to date. Thus, there is no regular understanding of green buildings. However, there are some terrible instances of green buildings that pursue the commercial interest in the name of green buildings. The reasons for this are a) limited understanding, b) lack of support, and c) unsatisfied assessment. Numerous individuals in China don't have a good comprehension of a green building [10]. They couldn't characterize what a green building is and would not perceive the standards and norms pertinent to green building development. Measures that encourage the construction of green buildings should be reinforced. Currently, there 
93 is little support in China for green technology in building design, and most green technology research is at an early stage

94 of development. Conventional building design and construction have historically failed to consider environmental 95 protection, and architectural technology; thus, thinking has modified little [11]. Although some attention has been given

96 to environmental protection, architects and designers still favour the traditional building technologies and construction methods utilized by their antecedents. Deficient consideration is given to specialized estimates that would reduce the effect of a structure on nature. [12]. Green building assessment methodologies in China are still in its initial stage than those used abroad. There is no unified green building code. Evaluation criteria must be standardized. The adoption of existing assessment methods has increased the use of environmental indicators, while economic and social indicators are ignored [10]. Environmental indicators in current green building standards mainly consider the impact of green buildings on people's material living conditions [12]. However, no indicators directly evaluate the economic and social consequences of green building construction; thus, they are not considered in the assessment of a green building [13].

Table 1: China green building evaluation system.

\begin{tabular}{|c|c|c|c|}
\hline Year Development area & System & $\begin{array}{l}\text { Assessmen } \\
\text { type }\end{array}$ & Range of application \\
\hline 1996 Hong Kong & HK-BREEAM & $\begin{array}{l}\text { New } \\
\text { existing o } \\
\text { buildings }\end{array}$ & $\begin{array}{l}\text { Site materials, indoor environment, } \\
\text { energy and water resources, quality } \\
\text { improvement, and performance creation }\end{array}$ \\
\hline 2001 Taiwan & EMGB & All types & $\begin{array}{l}\text { Water conservation index, greening } \\
\text { index, daily energy-saving index, water } \\
\text { resources index, waste reduction index, } \\
\text { CO2 reduction index, sewage, and waste } \\
\text { reduction index }\end{array}$ \\
\hline
\end{tabular}

2005 China Housing Industry China eco-housing Residence Chamber of Commerce technology assessment handbook
Environmental planning and design of the community, energy, and environment, indoor environment quality, residential water use, materials and resources

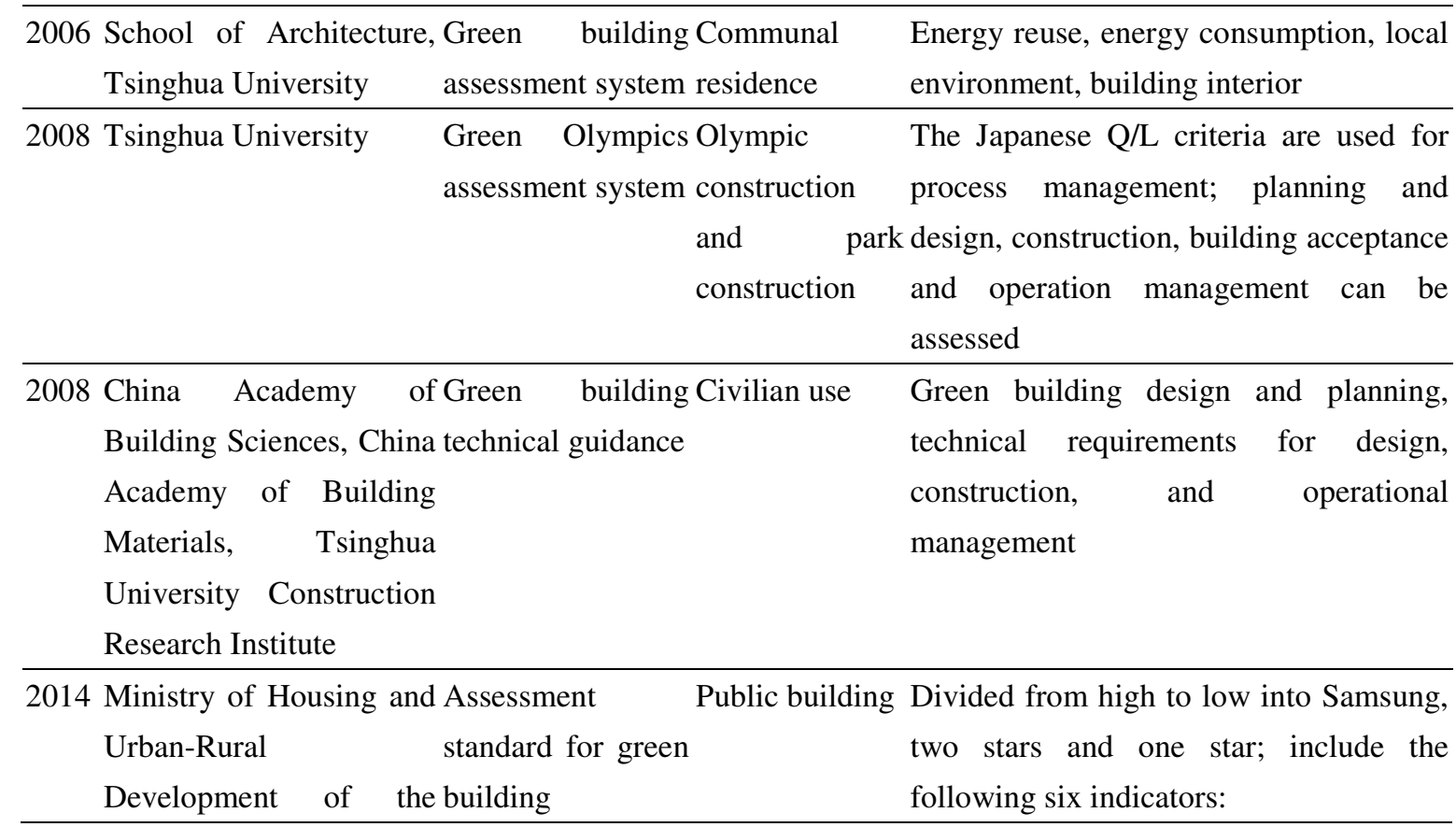




\begin{tabular}{llll}
\hline People's & Republic of & 1 Festivals and outdoor environment \\
China & & 2 Energy conservation and energy use \\
& 3 Water conservation and water use \\
& 4 Use of materials and materials \\
& resources \\
& 5 Indoor environmental quality \\
& 6 Operation management (residential \\
& buildings), full-life integrated \\
\hline
\end{tabular}

106

Numerous methodologies and strategies have been utilized by analysts to make green structure appraisal models: green probability analysis, comprehensive fuzzy analysis, hierarchical analysis, clustering analysis, fuzzy analytic hierarchy processes, and gray theory [14]. These procedures express to subjective, halfway subjective, and mostly quantitative ways to deal with evaluating green building plans and development. They are superior to obsolete strategies in thinking about vulnerability and distinguishing directional indexes. However, they do not evaluate randomness or uncertainty [15].

A new method was proposed by the researchers for evaluating green building construction. The cloud model is a numerical hypothesis created by $\mathrm{Li}$ and Shi that uses fuzzy set theory, probability, and statistical theory to quantify complex uncertainty [16]. The cloud model characterizes randomness, fuzziness, and variable correlations and it maps qualitative uncertainties to quantitative uncertainties [17]. The cloud model has been used to quantify the performance of green buildings by some researchers [18]. However, their models are not comprehensive or systematic.

An investigation has been accomplished for green building assessments by comparing the criteria used for green building assessment in China with those used in different countries. Quantitative and qualitative indexes for green building properties were consolidated to set up an evaluative model, which can be used for green building assessment. The main purpose of a green building assessment tool is to evaluate different aspects of sustainable practices during the planning, construction, and operation of a green building and to identify where and how to incorporate best practices to reduce the adverse effects of the building on the environment. A thorough comprehensive examination framework was also built up that utilizes a novel strategy to evaluate green building extends that are dependent upon uncertainty. The green building performance cloud model assessment method is shown in Figure 1.

\subsection{Research Methods and Procedures}

\subsection{The cloud model}

A cloud model transforms qualitative concepts into quantitative values [19-21]. Two key concepts of the cloud model, which creates mapping relationships, are its numerical characteristics and the cloud generators. Together, they reflect the interdependence of quality and quantity. The summary of the cloud model is as follows:

$C$ is a quantitative domain; $P$ is a qualitative semantic concept of $U ; x$ is a numerical value for $P(x \in U) ; \mu P(x)$ represents the degree of certainty that the random number $x$ represents $P ; x$ is a random number that tends towards a stable value; and $\mu P(x) \in[0,1]$ [22]. The distribution of $x$ in domain $\mathrm{C}$ is a cloud, and each value of $x$ value is a cloud drop $(x, \mu P(x))$ [23]. Many cloud drops converge into the cloud. Each cloud drop is represented as a point and the qualitative semantic concept $P$ is thus mapped onto a number field. Three numerical characteristics of the cloud (the expected value $E x$, entropy $E n$, and hypertrophy $H e$ ) quantify the qualitative concepts, as shown in Figure 2. 


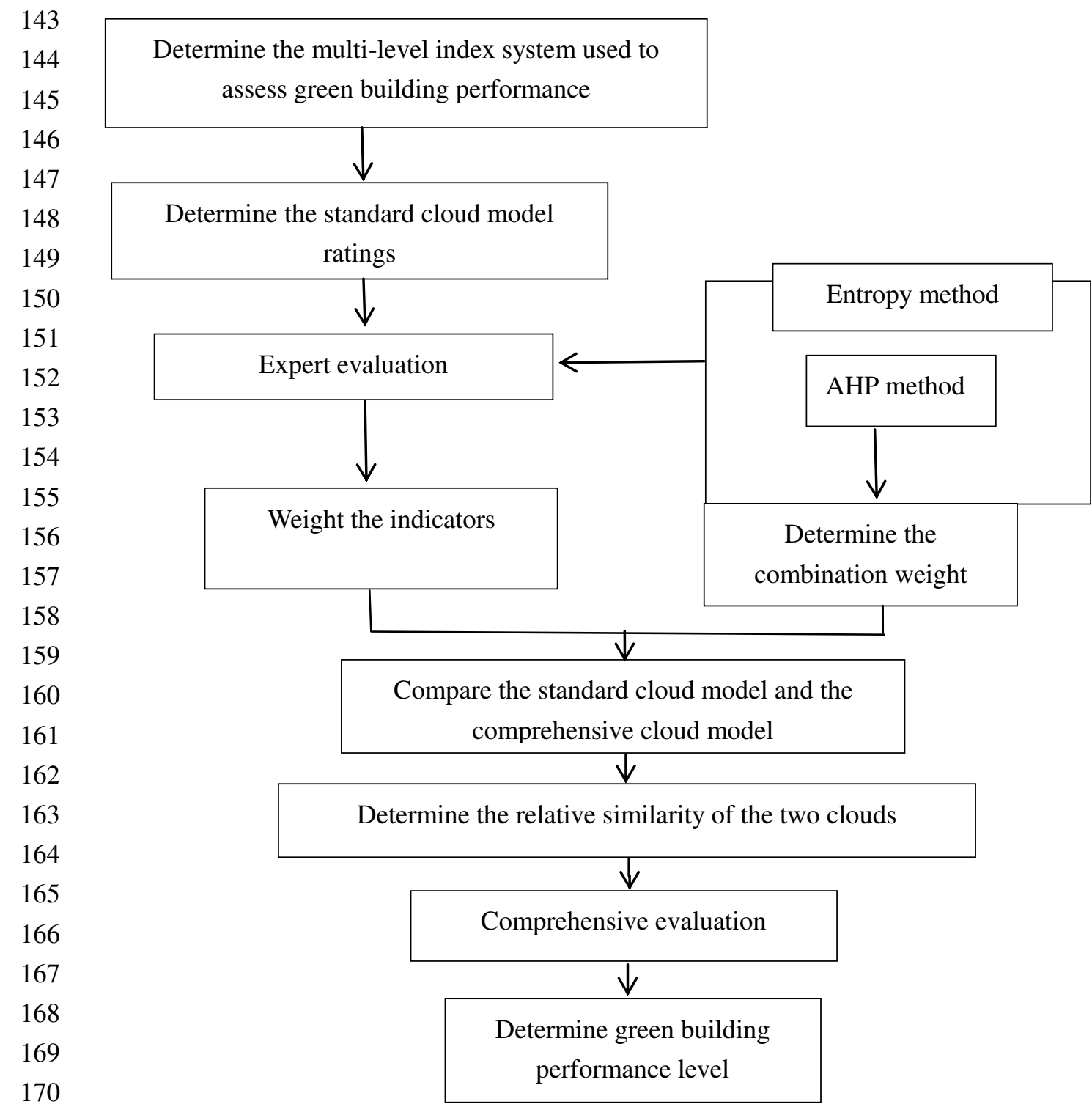

171

172

Fig. 1: Green building performance cloud model assessment method

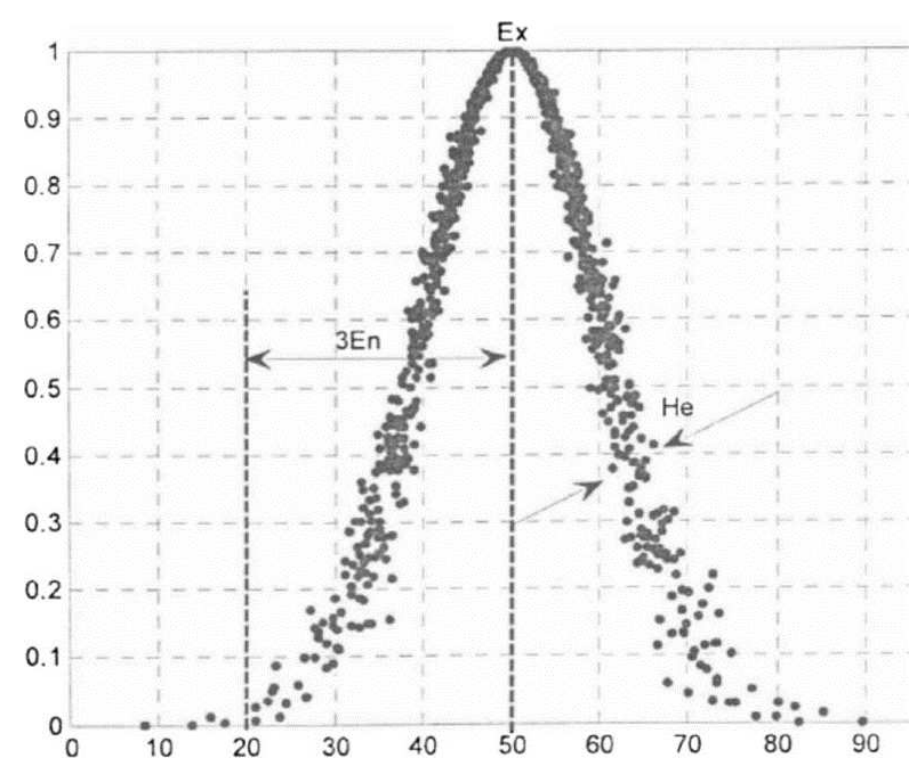

Fig. 2: Numerical characteristics of a cloud 


\subsection{Numerical characteristics of a cloud}

The expected value $E x$ is the most representative (mean) value of the qualitative concept in $C$, and it is the centric value of the number field space. En quantifies the qualitative concept $P$ and is determined by the fuzziness and randomness of the concept $P$. Entropy values indicate that the larger $E n$ values are, the more macroscopic $P$ is. A concept becomes more difficult to quantify when the fuzziness and randomness are associated with the concept increase. Hypertrophy He represents the uncertainty of $E n$ and is determined by the fuzziness and randomness of En. The uncertainty of all point sets represents qualitative concepts in the number field space (i.e., the decrease in cloud cohesion). Greater cloud drop dispersion is indicated by higher He values. The more random the cloud drops are, the greater the cloud thickness is.

\subsection{Cloud generators}

There are two cloud generators: the forward cloud generator, and the reverse cloud generator [19, 20, 23, 24]. The forward cloud generator derives the range and distribution of quantitative values from qualitative information by mapping the numerical characteristics of the cloud $(\mathrm{Ex}, \mathrm{En}, \mathrm{He})$ into cloud drops [25]. The reverse cloud generator converts the values represented by Ex,En, and $H e$ into semantically qualitative concepts (as shown in Figures 3 and 4 ).

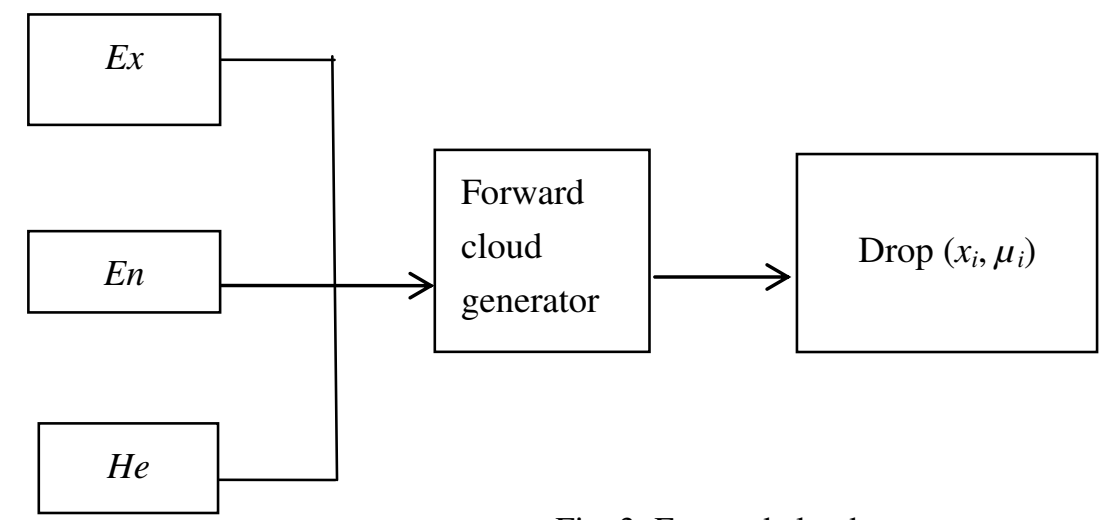

Fig. 3: Forward cloud generator.

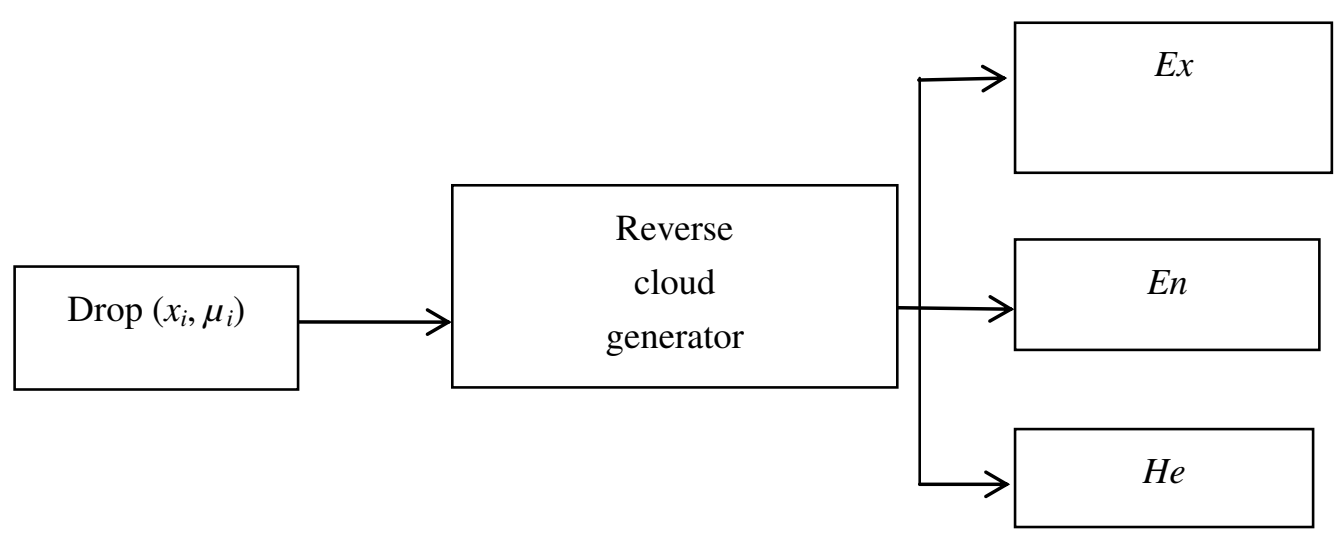

Fig. 4: Reverse cloud generator.

\subsection{Data Interpretation and Analysis \\ 4.1 Performance evaluation system for a green building project}


A multi-level index of building properties can be developed, by drawing on relevant literature [26-28], and policy analysis [29, 30] and using evaluative scoring. The index can be used to assess the performance of a green building [31]. Four first-level indexes (environmental-economic balance, regional social coordination, health and comfort, and green management) and 36 second-level indexes $(D 1-D 36)$ were identified. The green building assessment indexes and descriptions are shown in Table 2.

Table 2: Green building construction evaluation index system.

\begin{tabular}{|c|c|}
\hline \multicolumn{2}{|c|}{ Green building performance evaluation } \\
\hline Index & Description \\
\hline \multicolumn{2}{|c|}{ Environmental-economic balance } \\
\hline $\begin{array}{l}\text { Renewable } \\
\text { utilization, D1 }\end{array}$ & $\begin{array}{l}\text { Utilize the common states of building locales, adequately create and use } \\
\text { sustainable power source, and diminish natural contamination and } \\
\text { environmental damage caused by energy consumption. }\end{array}$ \\
\hline Energy efficiency, D2 & $\begin{array}{l}\text { On the another hand, it improves the efficient use of building energy; on the } \\
\text { other hand, choose reasonable equipment and take effective control measures. } \\
\text { Use energy recovery technology to release energy cascading and optimize } \\
\text { energy systems for different energy use structures. }\end{array}$ \\
\hline $\begin{array}{l}\text { Enclosure structure } \\
\text { energy-saving, D3 }\end{array}$ & $\begin{array}{l}\text { The building enclosure has a great effect on energy conservation, including } \\
\text { insulation technology in external walls, roofing, and ground. The utilization of } \\
\text { various advanced building energy-saving technologies can greatly improve } \\
\text { energy efficiency and reduce energy consumption [32]. }\end{array}$ \\
\hline $\begin{array}{l}\text { Utilization of } \\
\text { water-saving appliance, } \\
\text { D4 }\end{array}$ & $\begin{array}{l}\text { Measures such as water-saving appliances, water-saving systems, and the } \\
\text { recycling of water resources are used to improve building water use } \\
\text { efficiency, to diminish water utilization in the building, and to acknowledge } \\
\text { the goal of water-saving. }\end{array}$ \\
\hline $\begin{array}{l}\text { Recovery of water and } \\
\text { rainwater, D5 }\end{array}$ & $\begin{array}{l}\text { Identify local use of technology and economic conditions to make use of } \\
\text { rainwater and reclaimed water and water recovery systems; make full use of } \\
\text { construction, water by recycling it, reduce the environmental pressure of water } \\
\text { extracted from the natural environment, pay attention to the source and } \\
\text { regulate the flow of water. }\end{array}$ \\
\hline $\begin{array}{l}\text { Sewage recovery and } \\
\text { treatment, D6 }\end{array}$ & $\begin{array}{l}\text { Use rainwater and sewage diversion systems, ensure the comprehensive use of } \\
\text { rain, sewage water, and water safety; saving water can greatly alleviate the } \\
\text { increased demand because of water shortage. }\end{array}$ \\
\hline $\begin{array}{l}\text { Utilization of low } \\
\text { energy material, D7 }\end{array}$ & $\begin{array}{l}\text { Green buildings use building materials of low energy, high performance, low } \\
\text { resource consumption, and high durability, which reduces the use of } \\
\text { non-renewable resources; uses industrially produced finished products as } \\
\text { much as possible, and reduce construction waste. }\end{array}$ \\
\hline Green roof, D8 & Greening of rooftops. \\
\hline $\begin{array}{l}\text { The rate of green space, } \\
\text { D9 }\end{array}$ & The proportion of the green area. \\
\hline \multicolumn{2}{|c|}{ Regional social coordination } \\
\hline $\begin{array}{l}\text { Effective utilization of } \\
\text { land resources, D10 }\end{array}$ & $\begin{array}{l}\text { Reconstruction and redevelopment of existing land are an effective use of land } \\
\text { resources and an effective measure to improve land utilization rate. The } \\
\text { overall value of green building construction can be greatly increased by using }\end{array}$ \\
\hline
\end{tabular}




\begin{tabular}{|c|c|}
\hline & mplete public infrastructure support en of the surrounding land. \\
\hline $\begin{array}{l}\text { Protect the soil from } \\
\text { contaminated, D11 }\end{array}$ & $\begin{array}{l}\text { During the construction process, the soil will be polluted to some degree. A } \\
\text { suitable selection and layout of vegetation can adjust the microclimate of the } \\
\text { site, control soil erosion, and even remediate soil pollution. }\end{array}$ \\
\hline $\begin{array}{l}\text { Harmony with existing } \\
\text { buildings, D12 }\end{array}$ & $\begin{array}{l}\text { Architectural design should coordinate the overall built shape, including } \\
\text { existing buildings, spatial configuration, facade and colour, and the } \\
\text { surrounding environment [33]. }\end{array}$ \\
\hline $\begin{array}{l}\text { Interference with the } \\
\text { surrounding } \\
\text { environment, D13 }\end{array}$ & $\begin{array}{l}\text { The adverse effect of development exercises on the earth, for example, air } \\
\text { contamination, water contamination, light contamination, and noise } \\
\text { contamination, must be controlled to lessen impedance with the general } \\
\text { condition. }\end{array}$ \\
\hline $\begin{array}{l}\text { Impact on surrounding } \\
\text { public transport, D14 }\end{array}$ & $\begin{array}{l}\text { The architectural design is closely related to the surrounding site environment, } \\
\text { transportation network, and urban infrastructure. }\end{array}$ \\
\hline $\begin{array}{l}\text { Location of amenities, } \\
\text { D15 }\end{array}$ & The location of amenities. \\
\hline Free parking, D16 & The effect on green buildings of free parking. \\
\hline $\begin{array}{l}\text { Impact on peripheral } \\
\text { economic benefits, D17 }\end{array}$ & Economic benefits to the surrounding environment. \\
\hline \multicolumn{2}{|l|}{ Health and comfort } \\
\hline $\begin{array}{l}\text { Temperature } \\
\left({ }^{\circ}\right), \text { D18 }\end{array}$ & $\begin{array}{l}\text { Indoor temperature and humidity controls must meet the human body } \\
\text { temperature comfort requirements. }\end{array}$ \\
\hline Indoor air quality, D19 & $\begin{array}{l}\text { Utilize building configuration to improve common ventilation, the } \\
\text { circumstance of air outlets, and utilize new enlivening materials that can } \\
\text { improve indoor air quality. }\end{array}$ \\
\hline $\begin{array}{l}\text { Reasonable lighting and } \\
\text { sunshine level, D20 }\end{array}$ & $\begin{array}{l}\text { Toward the start of the compositional plan, natural light should be } \\
\text { incorporated as much as possible to create a good visual field with accessible } \\
\text { windows and to provide a comfortable indoor environment. }\end{array}$ \\
\hline $\begin{array}{l}\text { Acoustic performance, } \\
\text { D21 }\end{array}$ & $\begin{array}{l}\text { Dynamic and static partitions can divide the layout and space of the building, } \\
\text { and structural components of the building must be selected to reduce noise, to } \\
\text { ensure the office and living environment are quiet. }\end{array}$ \\
\hline $\begin{array}{l}\text { Indoor pollution } \\
\text { control, D22 }\end{array}$ & $\begin{array}{l}\text { Space layout is both logical and practical; human psychology and physiology } \\
\text { also should be taken into account. }\end{array}$ \\
\hline Indoor air quality, D23 & $\begin{array}{l}\text { Indoor materials can truly influence indoor air quality when they are a } \\
\text { significant wellspring of indoor contamination. }\end{array}$ \\
\hline Owner safety, D24 & $\begin{array}{l}\text { The architectural design should primarily consider the usability of the building } \\
\text { to ensure the safety of owners and occupants to improve the general building } \\
\text { design concept. }\end{array}$ \\
\hline $\begin{array}{l}\text { General design concept, } \\
\text { D25 }\end{array}$ & $\begin{array}{l}\text { General design, also known as all-around design or universal design, is the } \\
\text { built environment and communication systems that can be used by all building } \\
\text { users without modification. }\end{array}$ \\
\hline \multicolumn{2}{|l|}{ Green management } \\
\hline $\begin{array}{l}\text { Community } \quad \text { waste } \\
\text { management plan, D26 }\end{array}$ & $\begin{array}{l}\text { Consider the sustainability of the construction project life cycle, which is the } \\
\text { biggest feature of green buildings. Conventional construction projects only }\end{array}$ \\
\hline
\end{tabular}




\begin{tabular}{|c|c|}
\hline & $\begin{array}{l}\text { consider the investment in the early stages of the project and ignore the } \\
\text { maintenance costs in the later stage to ensure minimal investment. }\end{array}$ \\
\hline $\begin{array}{l}\text { Waste management in } \\
\text { construction, D27 }\end{array}$ & $\begin{array}{l}\text { Centralize disposal of construction waste during construction to improve the } \\
\text { building management system. }\end{array}$ \\
\hline $\begin{array}{l}\text { Operational waste } \\
\text { management, D28 }\end{array}$ & $\begin{array}{l}\text { Green building construction pays attention to community waste management } \\
\text { plans and wastes treatment during building construction and operation to } \\
\text { reduce environmental damage. }\end{array}$ \\
\hline $\begin{array}{l}\text { Long-term facility } \\
\text { maintenance plan, D29 }\end{array}$ & $\begin{array}{l}\text { The long-term follow-up of the building operation will allow the owner to } \\
\text { recognize and realize the benefits of building sustainable and to reduce future } \\
\text { maintenance of the facility for subjective reasons. }\end{array}$ \\
\hline $\begin{array}{l}\text { Building management } \\
\text { system, D30 }\end{array}$ & $\begin{array}{l}\text { At each stage of development, construction, and building use, the impact of } \\
\text { management decisions on the project is dynamic and variable and will affect } \\
\text { resource consumption of the building; it is also very important to maintain the } \\
\text { indoor and outdoor environment. }\end{array}$ \\
\hline $\begin{array}{l}\text { Facility maintenance } \\
\text { and operation expense } \\
\text { management, D31 }\end{array}$ & $\begin{array}{l}\text { A sound and effective management mechanism will conserve energy, reduce } \\
\text { waste and pollution, increase environmental protection, and reduce the } \\
\text { operating cost of a green building. }\end{array}$ \\
\hline $\begin{array}{l}\text { Owner recognition of } \\
\text { facility sustainability, } \\
\text { D32 }\end{array}$ & $\begin{array}{l}\text { Mainly an assessment of the relationships between economic and ecological } \\
\text { values of buildings at different stages emphasizes the management of building } \\
\text { processes and recognizes the green performance of buildings. }\end{array}$ \\
\hline $\begin{array}{l}\text { The integrated design } \\
\text { process, D33 }\end{array}$ & $\begin{array}{l}\text { Integrated design is the most basic step of green building construction and } \\
\text { determines the objectives and the plan of a green building. }\end{array}$ \\
\hline $\begin{array}{l}\text { Trial run management, } \\
\text { D34 }\end{array}$ & $\begin{array}{l}\text { Trial operation management identifies the goals of resource-saving and } \\
\text { reducing energy consumption in building operations. }\end{array}$ \\
\hline $\begin{array}{l}\text { Construction } \\
\text { management, D35 }\end{array}$ & Manage construction to reduce resource use and energy consumption. \\
\hline $\begin{array}{l}\text { Project } \\
\text { management, D36 }\end{array}$ & $\begin{array}{l}\text { Green building construction must control project costs, extend building life, } \\
\text { and reduce average costs. }\end{array}$ \\
\hline
\end{tabular}

\subsection{Green building performance in the cloud model}

Expert scoring was used to determine the importance of the defined indexes. The index weightings were determined using the analytical hierarchy process (AHP) weighting and entropy weighting. Weights were combined to create the subjective and objective weights of the 36 assessment indexes, and thus the evaluation scores of the clouds for the project [34-36]. Computing the similarity between clouds enables us to determine the green building performance score.

\subsection{Determination of the assessment criteria}

The assessment criteria $R$ were classified as $R=\left\{R_{1}, R_{2}, \ldots, R_{p}\right\}$. Four-step $(P=4)$ or five-step $(P=5)$ ratings are commonly used. Experts were invited to assess the system indexes in $C$ and to give them weights. AHP and entropy were used to assign a subjective weight and an objective weight to each index. Thus, the combined weight of the index was determined. The domain $C$ of the index value was divided into $P$ intervals depending on the hierarchic level. The interval $\left[x_{i}^{\text {min }}, x_{i}^{\text {max }}\right]$ was the $i$ interval. The characteristic values for the standard cloud Cloud $d_{y}$ corresponded to each interval. The quantifiers $E_{X i}, E_{N i}$, and $H_{E i}$ were calculated by [37]: 

$E_{N}, H_{E}$ ) was given by:

$$
\left\{\begin{array}{l}
E_{X i}=\left(x_{i}^{\max }+x_{i}^{\min }\right) / 2 \\
E_{N i}=\left(x_{i}^{\max }-x_{i}^{\min }\right) / 2 \sqrt{2 \ln 2} \\
H_{E} i=k
\end{array}\right.
$$

where $k$ is a parameterized constant which is determined according to the ambiguous threshold in different projects.

\subsection{Determination of green building performance for the comprehensive cloud}

After re-screening, thirty experts were selected to score the indexes. The experts were variously from a construction unit, construction management department, and green building research staff. They were approached to score the factors that were checked during the green building development measure.

Equations (2)-(4) were used to derive the evaluation cloud for all indicators to process the expert scoring, with $Y_{v}=\left(y_{v 1}, y_{v 2}, \ldots, y_{v 30}\right) \quad$ and $v=1,2, \ldots, 30$. The index was $C_{u w}\left(E_{x w}, E_{n w}, H_{e w}\right)$, with $w=1,2, \ldots, 30$ :

$$
E_{x i}=1 / V \times\left(\text { Sum from } v=1 \text { to } V \text { of } z_{v i}\right) \text { where } i=1,2, \ldots, 30
$$

$$
E_{n 1}=\sqrt{\frac{\pi}{2}} \times \frac{1}{V}\left(\text { Sum from v=1 to } \mathrm{V} \text { of }\left|\mathrm{zvi}_{\mathrm{i}} \mathrm{E}_{\mathrm{x}}\right|\right) \text { where } \mathrm{i}=1,2, . ., 30
$$

$$
H_{e i}=\sqrt{\left|S_{i{ }^{2} E_{n i}{ }^{2}}\right|} \text { wherei }=1,2, \ldots, 30
$$

The combined weight $\gamma_{w}$ was substituted into $C_{u w}$, and the comprehensive green building performance cloud $C\left(E_{X}\right.$,

7

(1)

$$
\left\{\begin{array}{l}
E_{X}=\sum_{w=1}^{24}\left(E_{x w} \cdot \gamma_{w}\right) \\
E_{N}=\sqrt{\sum_{w=1}^{24}\left(E_{w w}{ }^{2} \cdot \gamma_{w}\right)} \\
H_{E}=\sum_{w=1}^{24}\left(E_{e w} \cdot \gamma_{w}\right)
\end{array}\right.
$$

\subsection{Calculating Cloud similarity}

Finally, calculate cloud similarity and determine the performance assessment grade of green buildings. Cloud similarity can be calculated by the steps shown in Table 3. By comparing the similarity of the comprehensive cloud and the standard cloud, the greater the similarity, the closer the safety performance level of the prefabricated construction project is the evaluation level.

Table 3: The steps for calculating cloud similarity

\begin{tabular}{|l|l|l|}
\hline $\begin{array}{l}\text { Ste } \\
\mathrm{p}\end{array}$ & Solution content & Description \\
\hline
\end{tabular}




\begin{tabular}{|l|l|l|}
\hline 1 & $E_{X k}=\operatorname{Norm}\left(E_{N}, H^{2}\right)$ & $\begin{array}{l}E_{X k} \text { is a normalized random number, } E_{N} \text { is the } \\
\text { expected value and } H_{E}^{2} \text { is the variance. }\end{array}$ \\
\hline 2 & $x_{k}=\operatorname{Norm}\left(E_{x}, E_{x k}{ }^{2}\right)$ & $\begin{array}{l}x_{k} \text { is a normalized random number, } E_{X} \text { is the } \\
\text { expected value, and } E_{X k}^{2} \text { is the variance. }\end{array}$ \\
\hline 3 & $\mu_{k}=\exp \left(-\left(x_{k}-E_{X i}\right)^{2} / 2 E_{N i}^{2}\right)$ & $x_{k}$ is put into the standard cloud Cloud $d_{v}$ with score $i$. \\
\hline 4 & $\delta_{i=\frac{1}{n} \sum_{k-1}^{n} \mu_{k}}$ & $\begin{array}{l}\text { Repeat steps } 2 \text { and } 3 \text { to obtain cloud similarity until } \\
n \mu_{k} \text { values are generated. Normally, } n \text { is in the } \\
\text { range 10-20. }\end{array}$ \\
\hline
\end{tabular}

\subsection{Case Study Results and Findings \\ 5.1 Case study project overview}

The XiTi project is located in Shatoujiao, Yantian District, Shenzhen city. The project is bounded by Dongpu Haijing garden in the east, Palm Bay in the south, Waterfront Road in the west, and Financial Road in the north. The built land area is 0.81 ha while the total construction area is about 5.9 ha. The mainland use indicators are shown in Table 4.

Table 4: Technical and economic indicators.

\begin{tabular}{ll}
\hline Used land location & Quantity \\
\hline Total area of used land $\left(\mathrm{m}^{2}\right)$ & 8052.87 \\
Total covered area $\left(\mathrm{m}^{2}\right)$ & 58766.24 \\
Green $\underline{\text { area }}\left(\mathrm{m}^{2}\right)$ & 2415.9 \\
Plot ratio $(\%)$ & 4.50 \\
Density of building (fraction of coverage) $(\%)$ & 25.00 \\
Land area for roads and squares $\left(\mathrm{m}^{2}\right)$ & 1809.84 \\
Public area $\left(\mathrm{m}^{2}\right)$ & 5050 \\
Total parking spaces & 300 \\
Underground parking spaces & 25 \\
Ground parking spaces & 275 \\
\hline
\end{tabular}

\subsection{Determine the assessment criteria $R$ and calculate the evaluation criteria cloud}

Due to the project assessment grade difference, the project assessment is on a six-point scale: $R=\{$ very poor, poor, qualified, moderate, good, and excellent $\}$. The scores are in the interval $[0,100]$. The characteristic parameters of each level of assessment for the standard cloud model Cloud are given in Table 5.

Table 5: Standard scoring categories and the corresponding cloud models.

\begin{tabular}{lll}
\hline Performance rating standard & Interval partition & $\begin{array}{l}\text { Cloud } \\
\text { parameters }(E n, E x, H e)\end{array}$ \\
\hline Very poor, Cloud $_{1}$ & {$[0.0,20.0]$} & $(10,8.4932,0.5)$ \\
Poor, Cloud $_{2}$ & $(20.0,40.0]$ & $(30,8.4932,0.5)$ \\
Qualified, Cloud $_{3}$ & $(40.0,60.0]$ & $(50,8.4932,0.5)$ \\
${\text { Moderate, } \text { Cloud }_{4}}_{\text {Good, Cloud }_{5}}$ & $(60.0,80.0]$ & $(70,8.4932,0.5)$ \\
Excellent, Cloud $_{6}$ & $(80.0,90.0]$ & $(85,4.2466,0.5)$ \\
\hline
\end{tabular}


Table 5 gives the six performance ratings of the green building performance in a standard cloud. The cloud representation was obtained using Matlab 7.0 (Figure 5).

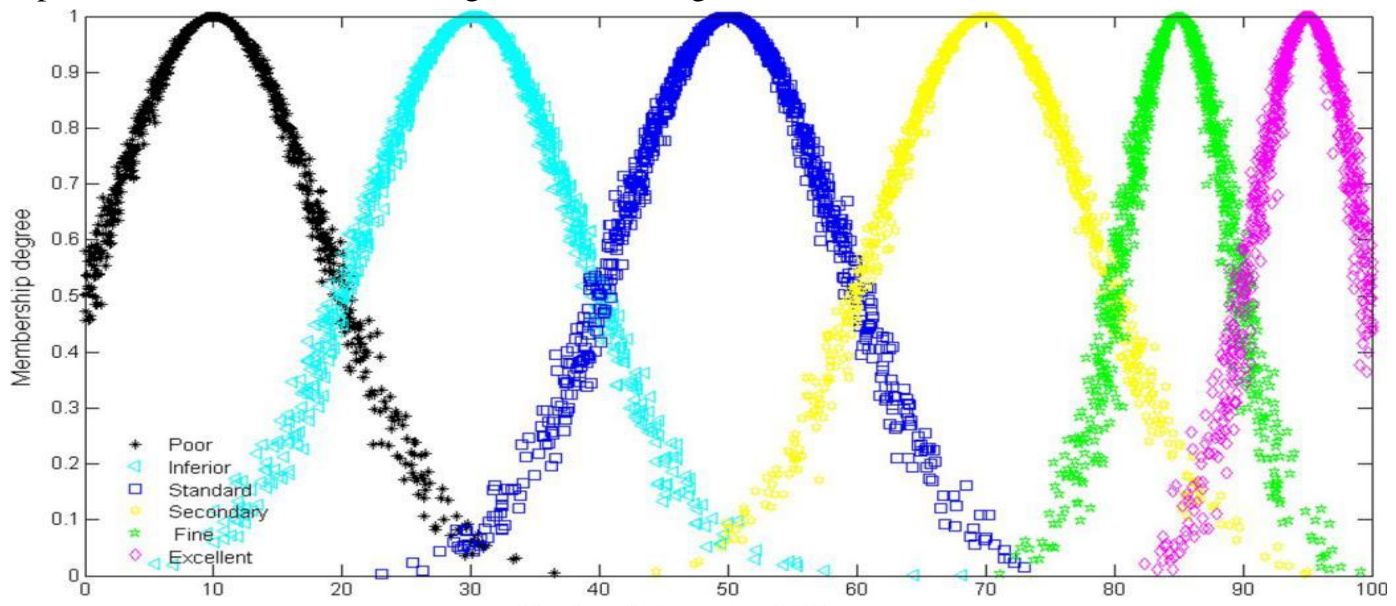

Fig. 5: Six-point evaluation standard cloud chart.

\subsection{Analysis of expert evaluation data and calculation of combined weights}

Thirty experts, engaged in the green building industry or research, were invited to evaluate the project's green performance. The experts calculate the subjective weight of the importance of the index and collect data of 30 similar projects to calculate the objective weight. Accordingly, a blend consolidated load of each list was acquired in Table 6 .

Table 6: Index weight and cloud characteristics.

Index Subjective weight Objective weight Combined weight Cloud characteristics

\begin{tabular}{lllll} 
& & & & $(E x, E n, H e)$ \\
\hline $\mathrm{D}_{1}$ & 0.07098 & 0.05985 & 0.14613 & $(82.42,2.62,1.37)$ \\
$\mathrm{D}_{2}$ & 0.05672 & 0.02793 & 0.05449 & $(91.92,4.32,0.65)$ \\
$\mathrm{D}_{3}$ & 0.00992 & 0.04102 & 0.01397 & $(88.09,3.62,1.36)$ \\
$\mathrm{D}_{4}$ & 0.02267 & 0.01743 & 0.01358 & $(87.92,4.32,1.26)$ \\
$\mathrm{D}_{5}$ & 0.02772 & 0.01642 & 0.01565 & $(82.47,4.63,0.56)$ \\
$\mathrm{D}_{6}$ & 0.04153 & 0.02842 & 0.04057 & $(89.02,3.89,1.16)$ \\
$\mathrm{D}_{7}$ & 0.03124 & 0.02932 & 0.03148 & $(83.93,4.05,0.97)$ \\
$\mathrm{D}_{8}$ & 0.02146 & 0.03922 & 0.02893 & $(89.82,2.48,1.55)$ \\
$\mathrm{D}_{9}$ & 0.06703 & 0.02038 & 0.04701 & $(90.33,4.03,1.36)$ \\
$\mathrm{D}_{10}$ & 0.00993 & 0.01934 & 0.00662 & $(91.23,3.42,0.75)$ \\
$\mathrm{D}_{11}$ & 0.02062 & 0.03795 & 0.02687 & $(86.77,4.99,1.01)$ \\
$\mathrm{D}_{12}$ & 0.01376 & 0.03974 & 0.01883 & $(81.25,2.32,0.92)$ \\
$\mathrm{D}_{13}$ & 0.00826 & 0.03582 & 0.01018 & $(83.42,2.02,0.91)$ \\
$\mathrm{D}_{14}$ & 0.01278 & 0.01083 & 0.00476 & $(93.71,2.83,0.91)$ \\
$\mathrm{D}_{15}$ & 0.00858 & 0.03662 & 0.01078 & $(82.28,1.76,0.61)$ \\
$\mathrm{D}_{16}$ & 0.01812 & 0.00995 & 0.00618 & $(92.38,2.56,1.16)$ \\
$\mathrm{D}_{17}$ & 0.04353 & 0.04922 & 0.07367 & $(84.68,5.09,1.47)$ \\
$\mathrm{D}_{18}$ & 0.02268 & 0.01074 & 0.00838 & $(94.95,2.28,1.02)$ \\
$\mathrm{D}_{19}$ & 0.01207 & 0.01403 & 0.00583 & $(81.16,3.52,0.46)$ \\
$\mathrm{D}_{20}$ & 0.03029 & 0.02015 & 0.02098 & $(86.65,3.58,1.72)$ \\
$\mathrm{D}_{21}$ & 0.01392 & 0.04052 & 0.01937 & $(81.26,4.62,1.07)$ \\
\end{tabular}


$\begin{array}{ll}\mathrm{D}_{22} & 0.04025\end{array}$

$\begin{array}{ll}\mathrm{D}_{23} & 0.04247\end{array}$

0.03752

0.03075

0.02015

0.03076

0.01433

0.03098

0.02931

0.01853

0.03222

0.03802

0.03070

0.02976

0.00274

0.02976

0.01971
0.05193

0.04491

0.01558

0.03537

0.02021

0.03876

0.02395

0.00717

0.02377

0.03351

0.03205

0.02086

0.00313

0.02413

0.02054
$(86.01,3.52,1.28)$

(83.91, 4.07, 1.66)

(92.01, 4.08, 0.71)

$(92.96,3.52,0.59)$

$(81.13,5.52,1.47)$

$(80.82,3.52,1.36)$

$(87.97,1.52,0.08)$

$(91.68,3.42,0.77)$

$(94.02,4.11,1.22)$

$(81.96,2.56,1.07)$

$(88.52,4.77,1.26)$

$(87.03,2.88,1.63)$

$(80.19,3.33,0.98)$

$(85.06,4.46,1.38)$

$(81.96,2.96,0.06)$

\subsection{Calculation of each index cloud and synthesized cloud}

The expert index weightings were used to construct the evaluation matrix. Each cloud $C_{U w}\left(E_{x w}, E_{n w}, H_{e w}\right)$ was calculated by equations (1)-(4). Index $D_{23}$ is used as an example. The 30 experts weighted Indoor air quality, $D_{23}$. The cloud $C_{D 23}(83.91,4.07,1.66)$ for the particular index was calculated. The comprehensive green building cloud is obtained by substituting all cloud indexes and the weighted indexes into the equation (5) (Figure 6).

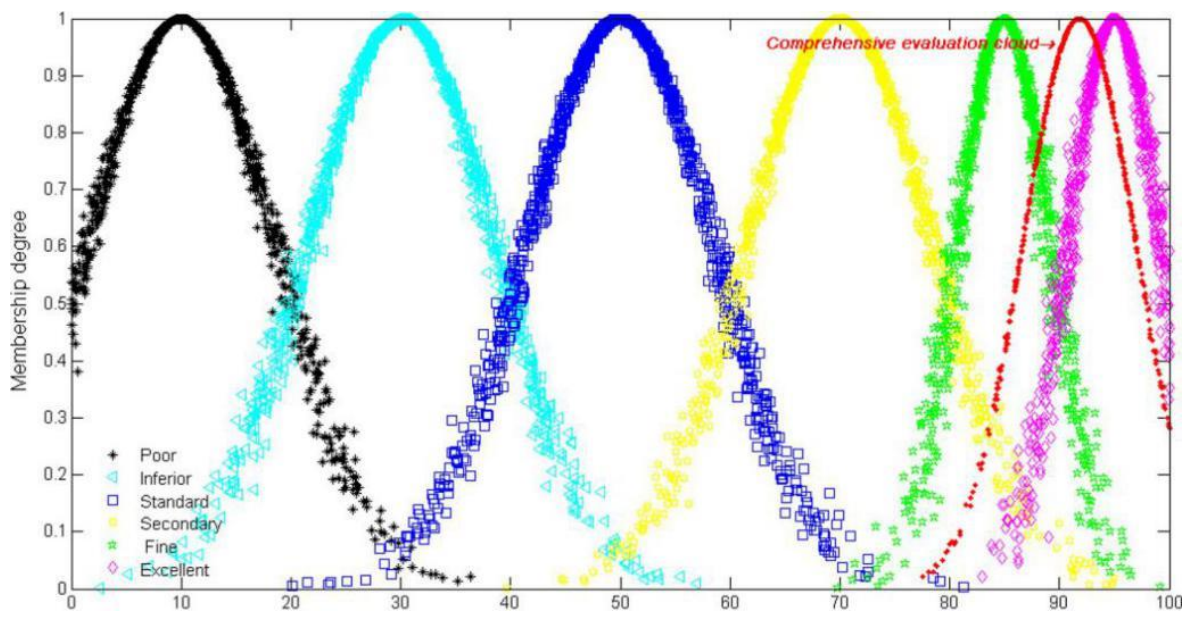

Fig. 6: Comprehensive cloud for green building evaluation

\subsection{Calculation of performance evaluation score by calculating similarity}

The similarity $b$ was calculated between the synthesized cloud $C(86.09 ; 3.64 ; 1.13)$ and used the standard cloud Cloud $_{v}$ (Table 7) to find that that similarity $b_{5}$ is the maximum; the corresponding performance rating for the green building project is Good.

Table 7: Similarity calculations. 


\begin{tabular}{lllllll}
\hline Standard value & Cloud $_{1}$ & Cloud $_{2}$ & Cloud $_{3}$ & Cloud $_{4}$ & Cloud $_{5}$ & Cloud $_{6}$ \\
\hline Similarity $b_{i}$ & 0.0001 & 0.0001 & 0.005 & 0.2423 & 0.7268 & 0.2115 \\
\hline
\end{tabular}

\subsection{Discussion}

Figure 6 shows that building performance assessment using the cloud model takes full account of any uncertainty, ambiguity, or randomness in the construction and operation of a green building. The overall cloud rating for this undertaking was Good and Excellent. From this examination, it can infer that its green exhibition is incredible. This contextual analysis exhibits the pertinence of the technique. Quantitative qualities and subjective ideas are joined to give a goal assessment. The assessment is introduced in two different ways, by the comparability esteem and the cloud maps, which settles on it simpler for decision-makers to assimilate and assess the information they receive.

\subsection{Conclusion}

Evaluating the benefits of installing a comprehensive energy-saving system in a building is a complex activity. It can be difficult to determine what characteristics of the system, reduce energy usage, and it can be hard to accurately quantify any characteristic affects the system as a whole. Regularly evaluation can be assessed inside a specific range (vulnerability and absence of exactness), or impacts can be portrayed semantically (unclearness and fluffiness). Sometimes such judgments overlap. Performance assessment of a green building is subject to temporal and spatial uncertainties. A Comprehensive green building evaluation turns into a multi-file and staggered cycle to assess these uncertainties. Consequently, a cloud model was developed to give an extensive evaluation of a green structure. This model assesses the vulnerability, fluffiness, and haphazardness inalienable in the appraisal by consolidating them into the development of cloud drops. The process of cloud drop formation transforms qualitative concepts into quantified values, making possible an objective mathematical evaluation of a building. A green building performance index that was created based on expert evaluations and weighted the indexes subjectively and objectively. Likewise, a standard cloud yardstick was also created in the comprehensive cloud. The sustainability of the building was qualified and assessed by comparing cloud images with the standard cloud. It has been analyzed that, the execution measurements and persuasive components make appraisal models for a green building. This investigation can help the development business to distinguish and manage issues that emerge in building green buildings. The coherent framework that the researchers have developed for assessing green buildings provides a solid foundation for further research into sustainability and green building operation. The result indicates that the industry acquires benefit by suggesting effective measures that can be implemented in all stages of green building construction. However, this study has a potential limitation. First, specific solutions to problems encountered in constructing green buildings must be made in collaboration with the government department. Secondly, the conclusions were drawn from considering Chinese green buildings, which makes them applicable only to China and their applicability in different nations is not yet clear. Green building construction involves many activities and many processes.

\section{References}

[1] Erlandsson, M., \& Borg, M. (2003). Generic LCA-methodology applicable for buildings, constructions and operation services - today practice and development needs. Building and environment, 38(7), 919-938.

[2] Horner, M., Hardcastle, C., Price, A., \& Bebbington, J. (2007). Examining the role of building envelopes towards achieving sustainable buildings.

[3] Nelms, C., Russell, A. D., \& Lence, B. J. (2005). Assessing the performance of sustainable technologies for building projects. Canadian Journal of Civil Engineering, 32(1), 114-128.

[4] Kibert, C. J. (2016). Sustainable construction: green building design and delivery. John Wiley \& Sons.

[5] Rawal, R., Vaidya, P., Ghatti, V., Ward, A., Seth, S., Jain, A., \& Parthasarathy, T. (2012, August). Energy code 
enforcement for beginners: a tiered approach to energy code in India. In ACEEE Summer Study on Energy Efficiency in Buildings (Vol. 3, pp. 313-324).

[6] Chaturvedi, V., Eom, J., Clarke, L. E., \& Shukla, P. R. (2014). Long term building energy demand for India: disaggregating end use energy services in an integrated assessment modeling framework. Energy Policy, 64, 226-242.

[7] Bhatt, R., \& Macwan, J. E. M. (2011). Global weights of parameters for sustainable buildings from consultants' perspectives in Indian context. Journal of Architectural Engineering, 18(3), 233-241.

[8] Ali, H. H., \& Al Nsairat, S. F. (2009). Developing a green building assessment tool for developing countries-Case of Jordan. Building and Environment, 44(5), 1053-1064.

[9] Vyas, G. S., \& Jha, K. N. (2016). Identification of green building attributes for the development of an assessment tool: a case study in India. Civil Engineering and Environmental Systems, 33(4), 313-334.

[10]Li, Y., Yang, L., He, B., \& Zhao, D. (2014). Green building in China: Needs great promotion. Sustainable Cities and Society, 11, 1-6.

[11]Ye, L., Cheng, Z., Wang, Q., Lin, H., Lin, C., \& Liu, B. (2015). Developments of green building standards in China. Renewable energy, 73, 115-122.

[12]Zhang, Y., Wang, J., Hu, F., \& Wang, Y. (2017). Comparison of evaluation standards for green building in China, Britain, United States. Renewable and sustainable energy reviews, 68, 262-271.

[13]Wei, G. A., \& Wang, J. Z. (2019). Analysis on National Environment of Green Building Assessment Scheme in America and China. In E3S Web of Conferences (Vol. 136, p. 03022). EDP Sciences.

[14]Liu, T. Y., Chen, P. H., \& Chou, N. N. (2019). Comparison of Assessment Systems for Green Building and Green Civil Infrastructure. Sustainability, 11(7), 2117.

[15]Ren, Y., Zhao, L., Song, Y., \& Lin, S. (2019, November). State assessment method for transformer under DC bias based on gray cloud model. In 2019 IEEE Sustainable Power and Energy Conference (iSPEC) (pp. 2282-2286). IEEE.

[16] Li, D. Y., Meng, H. J., \& Shi, X. M. (1995). Membership of cloud and subordinate cloud generator. Computer Research and Development, 32(6), 15-20. [19]Ding, Z., Fan, Z., Tam, V. W., Bian, Y., Li, S., Illankoon, I. C. S., \& Moon, S. (2018). Green building evaluation system implementation. Building and Environment, 133, 32-40.

[17] Banaitiene, N., Banaitis, A., Kaklauskas, A., \& Zavadskas, E. K. (2008). Evaluating the life cycle of a building: A multivariant and multiple criteria approach. Omega, 36(3), 429-441.

[18]Liu, Z., Wang, Q., JL Gan, V., \& Peh, L. (2020). Envelope Thermal Performance Analysis based on Building Information Model (BIM) Cloud Platform—Proposed Green Mark Collaboration Environment. Energies, 13(3), 586.

[19] Du, X. Y., Yin, Q. J., Huang, K. D., \& LIANG, D. N. (2008). Transformation between qualitative variables and quantity based on cloud models and its application. Systems Engineering and Electronics, 30(4), 772-776.

[20] Liu, G., Song, C. X., \& Liu, H. (2007). The software implementation of Cloud generator. Computer Application Research, 1, 46-48.

[21] Zhou, J., Zhu, Y. Q., Chai, X. D., \& Tang, W. Q. (2012). Approach for analyzing consensus based on cloud model and evidence theory. Systems Engineering-Theory \& Practice, 32(12), 2756-2763.

[22] Li, C. Z., Hong, J., Xue, F., Shen, G. Q., Xu, X., \& Luo, L. (2016). SWOT analysis and Internet of Things-enabled platform for prefabrication housing production in Hong Kong. Habitat International, 57, 74-87.

[23] Lu, H., Wang, Y., Li, D., \& Liu, C. (2003). The application of backward cloud in qualitative evaluation. Chinese Journal of Computers-Chinese Edition, 26(8), 1009-1014.

[24] Du, X. Y., Yin, Q. J., Huang, K. D., \& LIANG, D. N. (2008). Transformation between qualitative variables and quantity based on cloud models and its application. Systems Engineering and Electronics, 30(4), 772-776.

[25]Zhou, J., Zhu, Y. Q., Chai, X. D., \& Tang, W. Q. (2012). Approach for analyzing consensus based on cloud model and evidence theory. Systems Engineering-Theory \& Practice, 32(12), 2756-2763.

[26] Li, Y. Y., Chen, P. H., Chew, D. A. S., Teo, C. C., \& Ding, R. G. (2011). Critical project management factors of AEC 
firms for delivering green building projects in Singapore. Journal of Construction Engineering and

395 Management, 137(12), 1153-1163.

396 [27] Kibert, C. J. (2016). Sustainable Construction: green building design and delivery. John Wiley \& Sons.

[28] Alyami, S. H., Rezgui, Y., \& Kwan, A. (2013). Developing sustainable building assessment scheme for Saudi Arabia:

Delphi consultation approach. Renewable and Sustainable Energy Reviews, 27, 43-54.

[29] Alyami, S. H., \& Rezgui, Y. (2012). Sustainable building assessment tool development approach. Sustainable Cities and Society, 5, 52-62.

[30] Wedding, G. C., \& Crawford-Brown, D. (2007). Measuring site-level success in brownfield redevelopments: A focus on sustainability and green building. Journal of Environmental Management, 85(2), 483-495.

[31]Zou, X., \& Moon, S. (2014). Hierarchical evaluation of on-site environmental performance to enhance a green construction operation. Civil Engineering and Environmental Systems, 31(1), 5-23.

[32]Li, X., Zhu, Y., and Zhang, Z., 2010. An LCA-based environmental impact assessment model for construction processes. Building and Environment, 45 (3), 766-775.

[33]Vyas, G. S., \& Jha, K. N. (2016). Identification of green building attributes for the development of an assessment tool: a case study in India. Civil Engineering and Environmental Systems, 33(4), 313-334.

[34] Feng, Z., \& Zhang, H. W. (2017). "AHP-entropy weight method" based CW-TOPSIS model for predicting rockburst. China Safety Science Journal, 27, 128-133.

[35] Qiyue, C. (2010). Structure entropy weight method to confirm the weight of evaluating index. Systems Engineering 412 Theory \& Practice, 30(7), 1225-1228.

413 [36] Jin-Shi, X., Jian-Hua, L., \& Ying-Hui, Y. (2012, November). Method of Determine Index Weight in Security Risk 414 Evaluation Based on Information Entropy. In 2012 Fourth International Conference on Multimedia Information $415 \quad$ Networking and Security (pp. 43-48). IEEE.

416 [37] Li, Y. P., Liu, M. Q., Wang, F., \& Li, R. G. (2017). Safety performance assessment of prefabricated building project based on cloud model. China Safety Science Journal, 27(6), 115-120.

The Fujian agriculture and forestry university Ethical Review Board approached this study with consent to participate.

\section{- $\quad$ Consent for publication}

All authors have consent for publication.

\section{- $\quad$ Availability of supporting data}

428 All data generated or analysed during this study are included in this published article

\section{$430 \quad-\quad$ Competing interests}

431 The authors declare that they have no competing interests 
434 This research was funded by Huaqiao University, Grant no. 17BS201, and Quanzhou City Government, Grant no. $435 \quad 600005-Z 17 X 0234$

436

$437 \quad$ - $\quad$ Authors' contributions

438 Xiao-Juan Li conducted the data collection, Chen Wang conducted the data analysis, Shilpi Bora drafted the first writing, 439 Bimenyimana Samuel was in charge of the methodology.

440

$441 \quad-\quad$ Acknowledgements

442 This research was funded by Huaqiao University, Grant no. 17BS201, and Quanzhou City Government, Grant no. 443 600005-Z17X0234.

444 
Figures

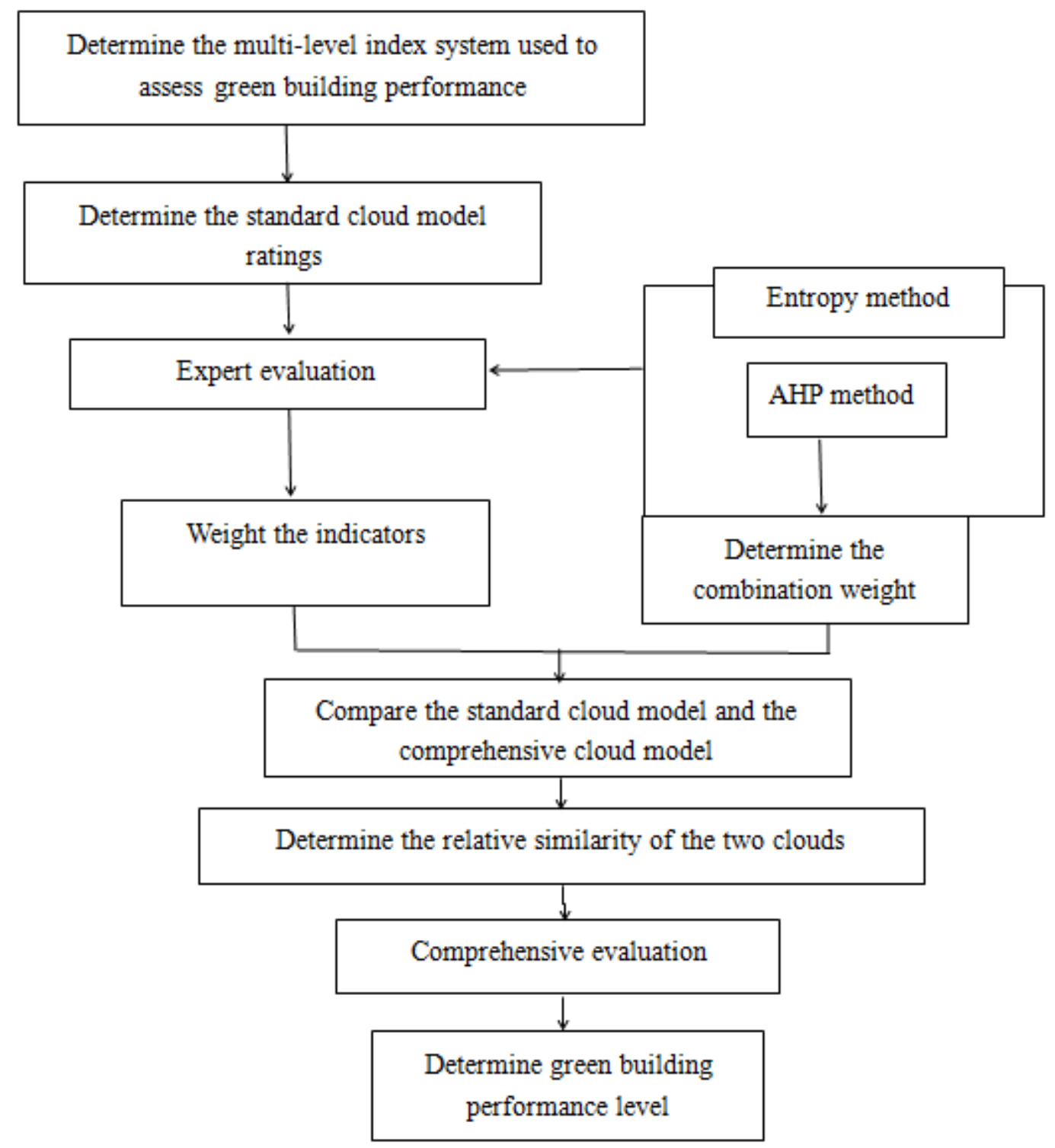

Figure 1

Green building performance cloud model assessment method 


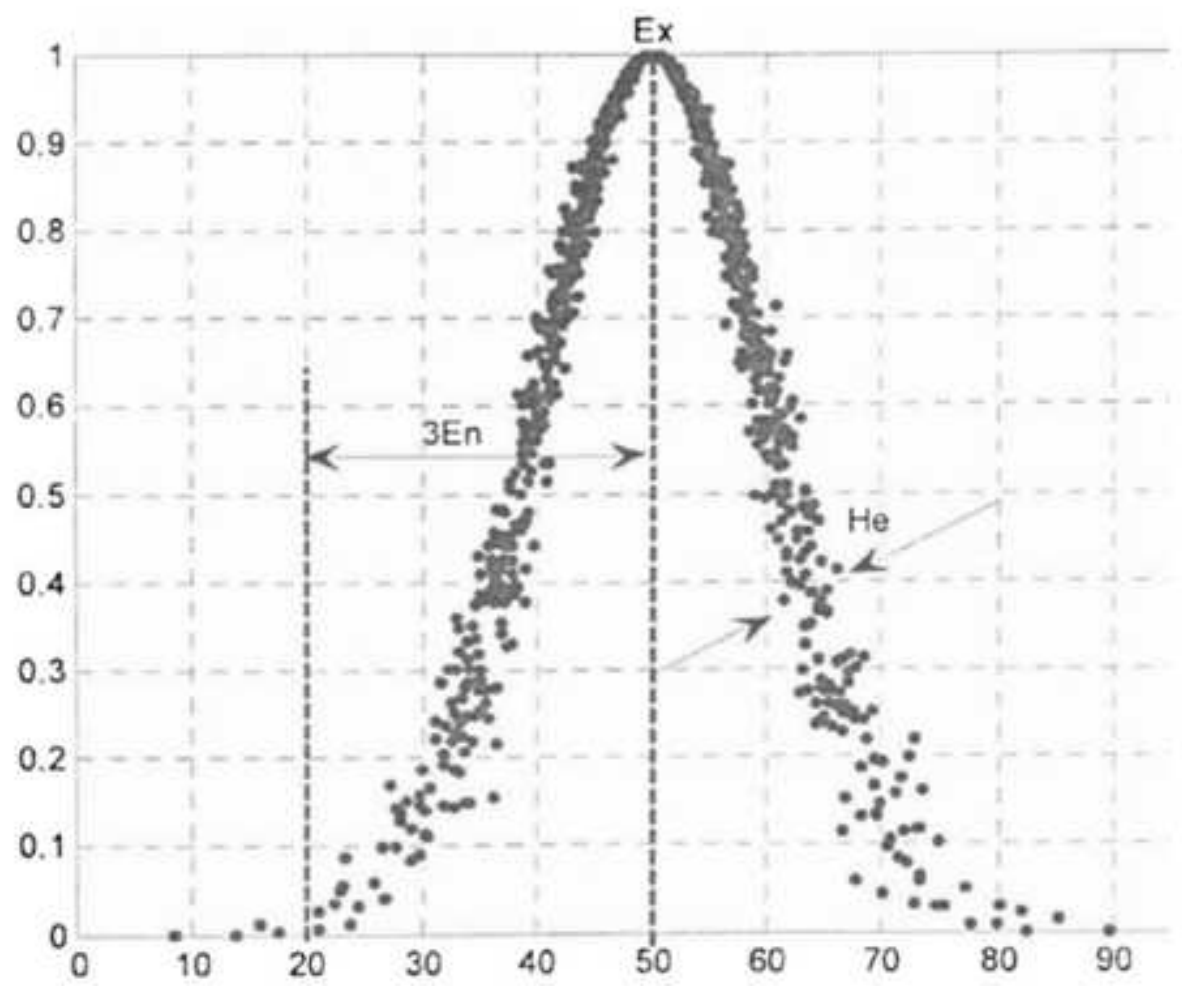

Figure 2

Numerical characteristics of a cloud

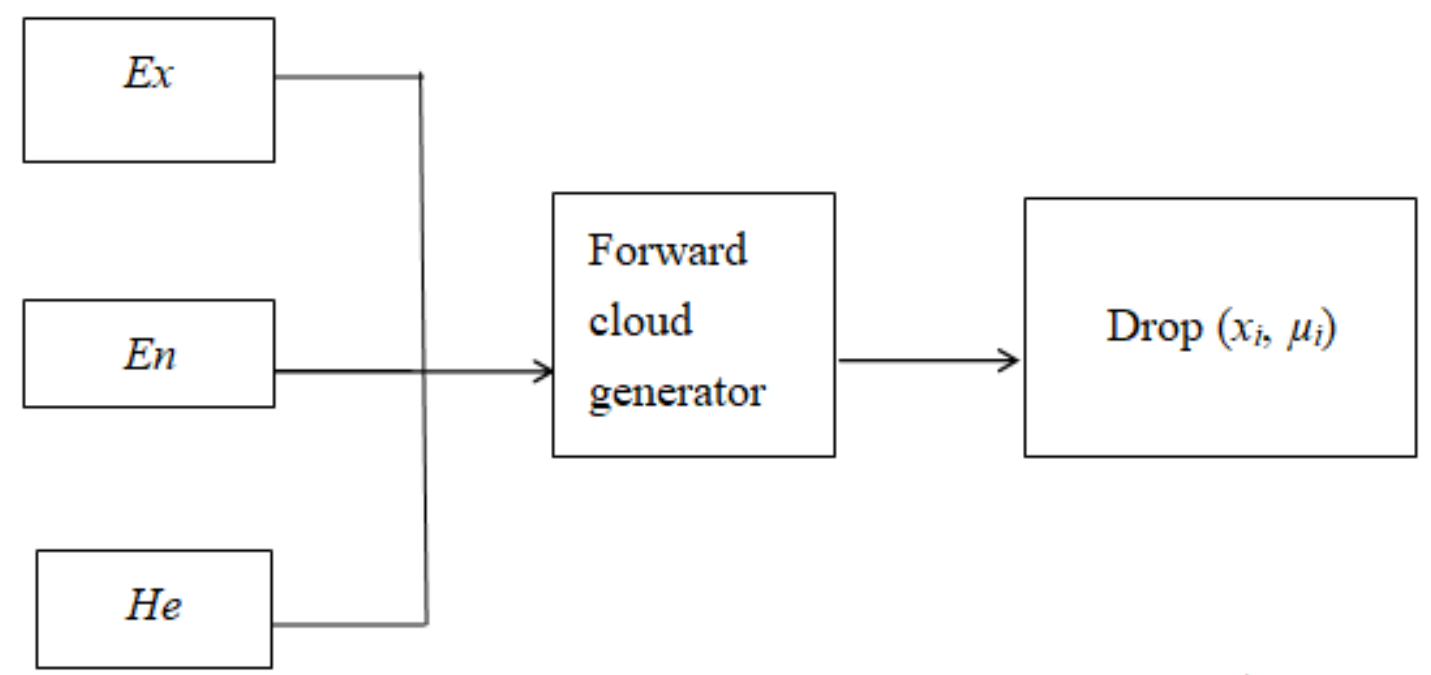

Figure 3

Forward cloud generator. 


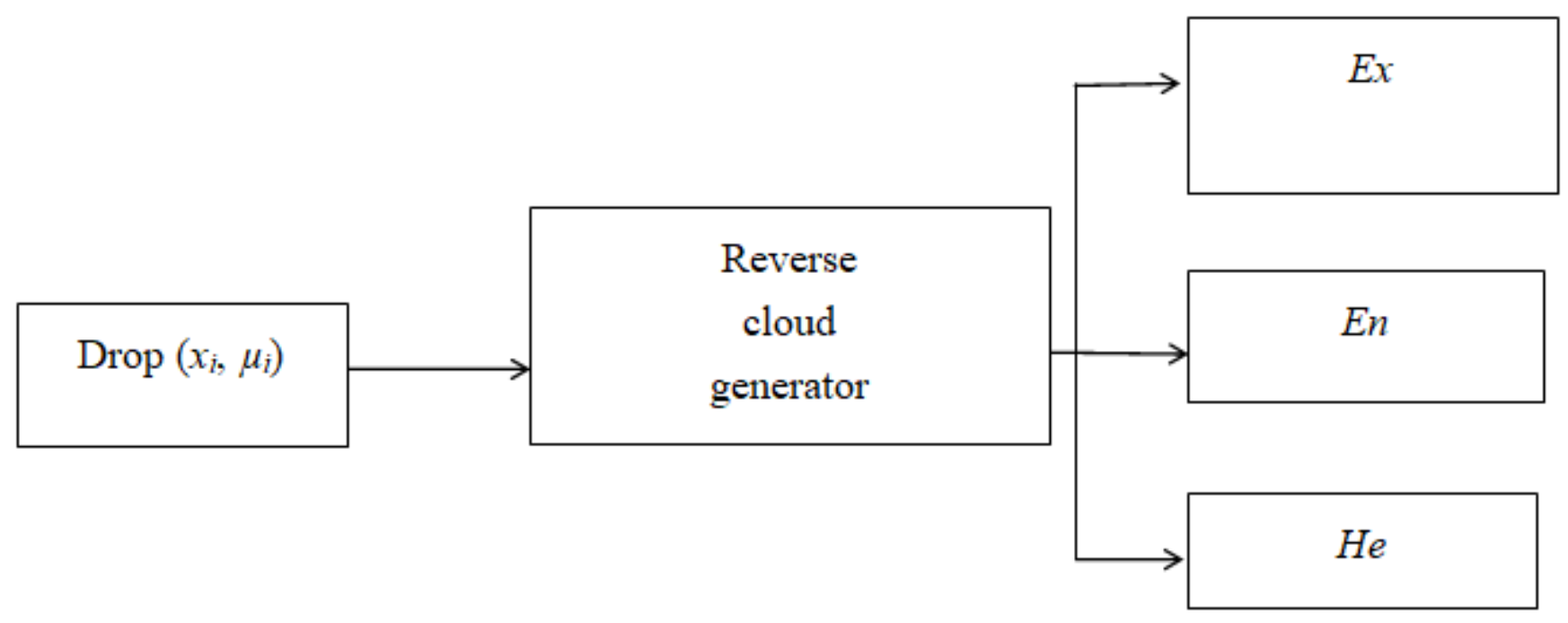

Figure 4

Reverse cloud generator.

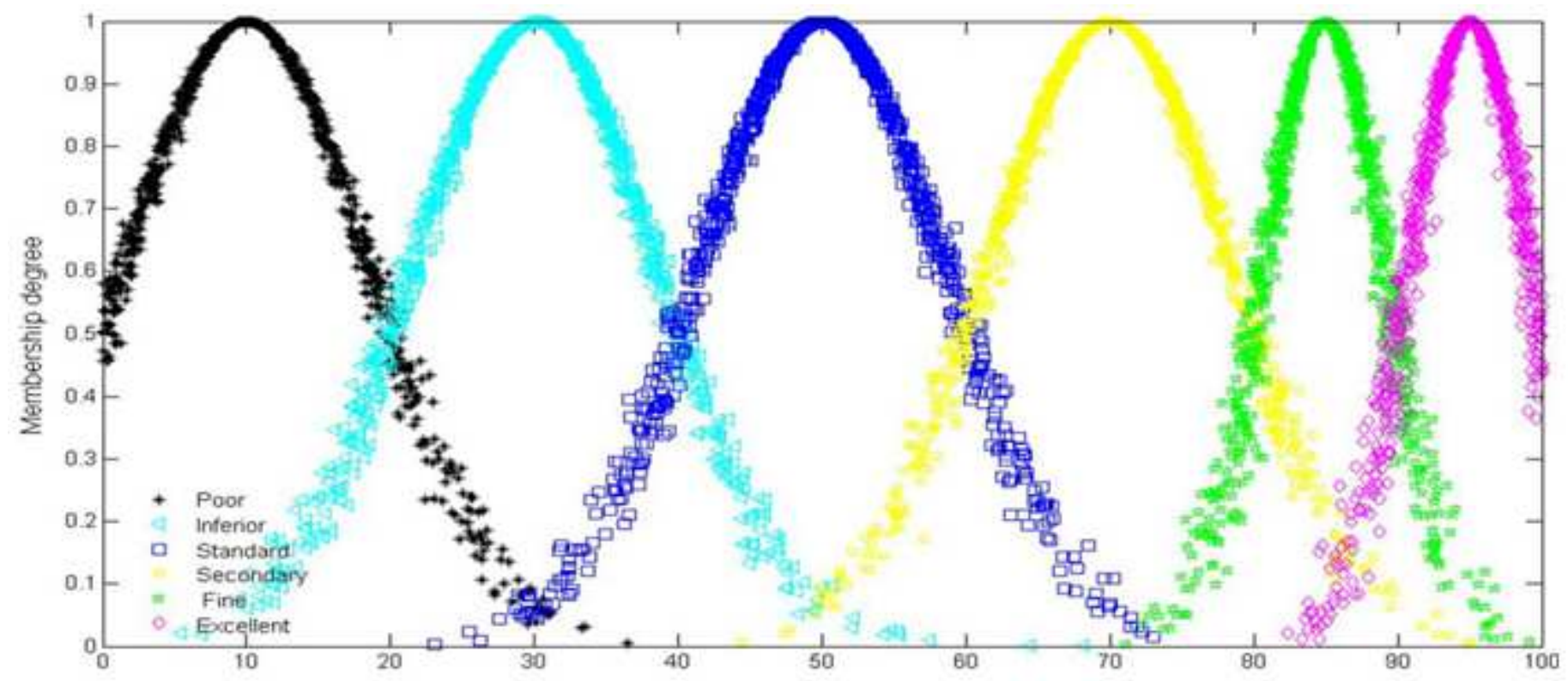

Figure 5

Six-point evaluation standard cloud chart. 


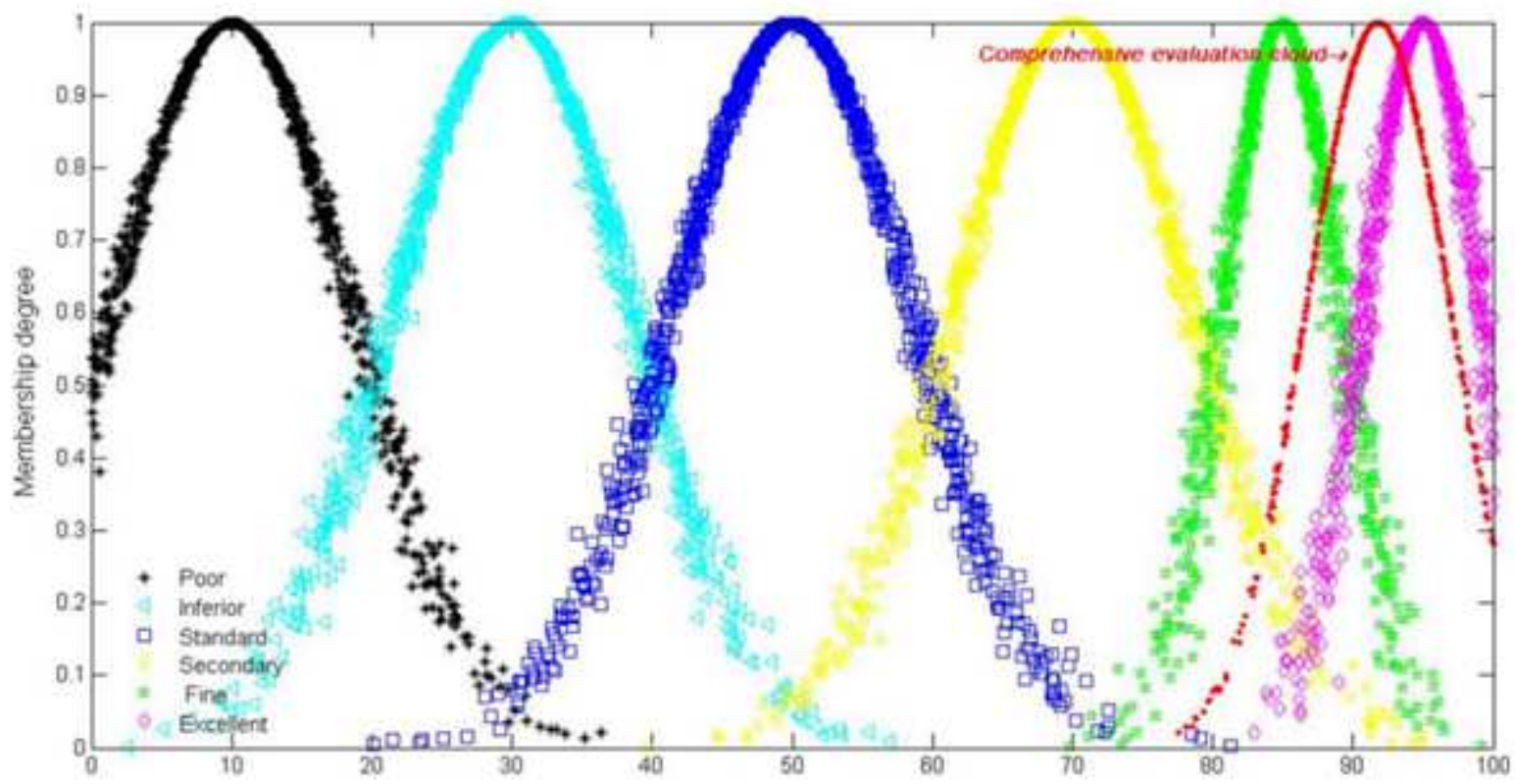

Figure 6

Comprehensive cloud for green building evaluation 